\section{Rocket man}

One of Saddam Hussein's senior

weapons designers tells Geoff Brumfiel of his past, and of his hopes for a new career.

$\mathrm{T}$ he former Iraqi rocket scientist is eager to show off his photographs. Deftly extracting them from a dusty briefcase beneath his chair, he flips through images of friends, colleagues, and himself standing in the desert in a blue Iraqi Air Force uniform.

But it is with paternal pride that he leafs through pictures of his rockets. He has dozens of photos showing missiles he helped to design shooting skyward, and he can rattle off technical details for each model - how far it flew and what its fuel system was. "We built these out of nothing," he reminisces.

For more than 40 years, 24 of them under the ultimate supervision of Saddam Hussein, Nadeem (not his real name) was a senior scientist in Iraq's military rocket programme.

On 18 September, he was one of six former Iraqi weapons scientists who flew to Washington for a week of meetings organized by the Civilian Research and Development Foundation (CRDF), a small non-profit organization devoted to keeping former weaponeers from Russia, Iraq and elsewhere in gainful employment by linking them with legitimate private industry in the West.

At the CRDF's headquarters in Arlington, Virginia, Nadeem agreed to talk to Nature about his career under Saddam Hussein and his fears for the future. A Sunni Muslim from a well-off family in northern Iraq, Nadeem joined the military straight from high school in 1963. The army sent him to a university in the United States to study mechanical engineering, and he returned six years later to begin work as a rocket designer.

This was a turbulent time in Iraq's history. Following the execution of King Faisal II in 1958, violent coup attempts were frequent. But Nadeem says that weapons researchers were doted on, whoever was in power. "The government looked at us as angels from heaven," he says. "Computers were not wellknown back then, but we had computers." Researchers from allied countries such as Egypt were brought in to provide additional training in specialist fields such as aerodynamics and thermodynamics.

After Saddam Hussein came to power in 1979, military scientists continued to receive generous funding, Nadeem recalls, but they fell under tighter scrutiny than ever before.

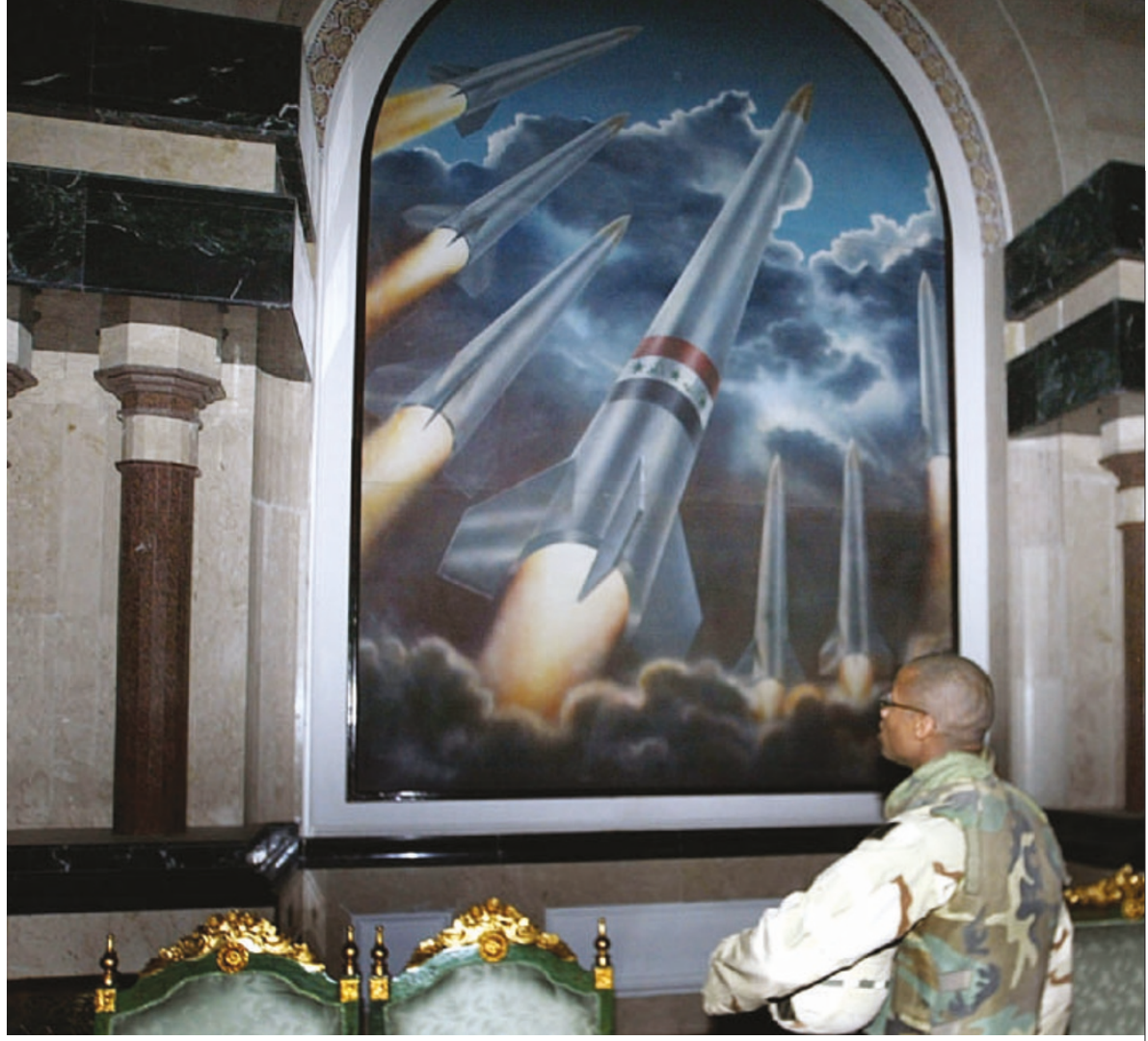

Friends in high places: US troops found a tribute to Iraq's rockets in one of Saddam Hussein's palaces.

"Saddam took care of the scientists, but if you spoke out against him he would execute you," he says. The headquarters of Iraq's stateowned Military Industrialization Corporation were bugged, Nadeem says. He recalls how, in 1991, security officials overheard a fellow designer criticizing Hussein's invasion of Kuwait. Within days the researcher disappeared, never to be seen again.

\section{In the firing line}

Nadeem had risen in this period to a very senior position in the Iraqi rocket programme, but his professional life got more difficult after the 1991 Gulf War. In order to comply with UN sanctions following the war, he says, Iraq shut down the rocket programme and sent him and his colleagues home. He lived off savings at first, and then by buying and selling used car parts, which were in desperately short supply under the UN embargo.

The UN then played an unintended role in reviving Nadeem's career, he says. "The UN brought me back," he remembers with a laugh. During a 1997 interview with UN weapons inspectors, a senior Iraqi official present was so impressed by Nadeem's knowledge that he rehired him as a consultant to one of Iraq's remaining rocket programmes.

For five years, Nadeem worked feverishly on the design of short-range surface-tosurface missiles, using whatever spare parts he could obtain and often building components from scratch. "We scrounged for what we could," he recalls. Despite the embargoes, he says, he developed a rocket that could fly upwards of $150 \mathrm{~km}$ - the limit permitted in Iraq at the time by the UN. Success won Nadeem and his colleagues a personal audience with Saddam in 2002 - but colleagues advised him not to go, on account of his outspokenness. "They were afraid I would get them into trouble," he says.

When the US-led coalition invaded Iraq in March 2003, some of Nadeem's missiles were fired at US forces. As US tanks swept north towards Baghdad, he thought the factory that made the rockets would be among their early ports of call. "We were expecting to be hit by a cruise missile," he recalls. But no missile came. Instead, looters ransacked the factory's design office. "The Americans could have given the order for a tank to stop at every agency, every university," he says angrily. "But they did nothing."

Today, Nadeem works in a mid-level administrative position at the newly formed Ministry of Science and Technology in Baghdad. He isn't happy with the status or the salary of his current position - he earns just half of his former salary - and he has dismal pension prospects, despite four decades in the armed forces. Many of his former colleagues are out of work and some ended up in prison.

Unlike other scientists at the CRDF conference, whose skills in biology or chemistry could be transferred to the private sector, the skills of the rocket-builder have few nonmilitary applications. One CRDF official describes him as "a special case".

Nadeem says he is uncertain about what will come next. Perhaps he will seek new work outside weaponry. "I'd love to do that," he says. "But after a 41-year career, it would be hard to do. I would like to work in my field, maybe for NASA - if they need me, I am ready."

Geoff Brumfiel is Nature's Washington physical sciences correspondent. 